\title{
Clientelism and the classification of dominant party systems*
}

\section{Aris Trantidis}

The view of clientelism as an abuse of state power casts doubt on the democratic credentials of highly clientelistic political systems. The question is particularly relevant for the classification of dominant party systems that heavily rely on clientelism to elicit popular support and retain a relatively open structure of participation. Knowing that clientelism is a widespread practice in modern democracies too, how do we evaluate the impact of clientelism on political competitiveness in order to sort out the position of these regimes along the lines of democracy and authoritarianism? This task requires identifying the conditions under which clientelism becomes an essentially authoritarian practice and qualifies these regimes as such. The article puts forward two propositions about the circumstances under which clientelism infringes basic democratic standards under a thin and a thick definition of democracy. Clientelism under one-party monopoly engenders authoritarianism when it thwarts and punishes the contesting voice of citizens by effectively blocking exit from its incentives and sanctions.

* This is an earlier draft of the eponymous paper published in Democratization, 2015, Volume 22, Issue 1, pp. 113-133.

Keywords: clientelism, dominant party systems, authoritarianism, patronage, democracy, semiauthoritarianism, hegemonic regimes, party politics, political competition 


\section{Introduction: Conceptual problems with the classification of dominant party systems}

Conceptual ambiguity surrounds the classification of dominant party systems as either democratic or authoritarian party systems, ${ }^{1}$ and, alternatively, their positioning along the range of semiauthoritarianism in which regime types are placed somewhere between the poles of democracy and typical authoritarianism. A plethora of regime labels such as 'sultanistic regimes', 'demagogical democracies', 'competitive authoritarianism', 'flawed', 'managed' or 'guided' democracies tend to illustrate specific deficiencies observed in the political systems to which they have been attached. ${ }^{2}$ These overlapping regime typologies clearly indicate that the line separating democratic from non-

democratic party systems is ill-defined. Labels such as 'hegemonic regimes', 3 'electoral authoritarianism' 4 and 'competitive authoritarianism' 5 broaden the conceptual reach of authoritarianism and include dominant party systems where despite regular and competitive multiparty elections 'the existence of formally democratic political institutions, such as multi-party electoral competition, masks the reality of authoritarian domination' ${ }^{6}$ These are settings where the prospect of electoral defeat for the dominant party seems to be 'a very unlikely event in the foreseeable future', ${ }^{7}$ and other parties are 'permitted to exist' but they do not become 'effective political competitors'. ${ }^{8}$ Not surprisingly, the extended notion of authoritarianism has been criticized for conceptual stretching. ${ }^{9}$ 
This stretch of the notion of authoritarianism beyond typical autocracies implicitly draws on Robert Dahl's thick and more substantive understanding of democracy as polyarchy, a political system with an open structure of participation and low levels of contestation, ${ }^{10}$ and his separate type of 'inclusive hegemony' defined as a regime with no serious flaws in the formal structure of participation (unlike typical autocracies) yet characterized by limited inter-party contestability. ${ }^{11}$ Here the absence of regular alternation of parties in government becomes the standard by which to classify party systems as non-democracies, ${ }^{12}$ and the conceptual boundaries of authoritarianism may go as far as to include all dominant party systems that emerge in a relatively open structure for political participation regardless of the means by which a low degree of inter-party contestability is achieved. Understandably, regime classification based on the concept of polyarchy can be criticized for reflecting a deontological and highly debatable conception of democracy that stands in contrast to a thin definition of democracy as an 'institutional arrangement for arriving at political decisions in which individuals acquire the power to decide by means of a competitive struggle for the people's vote'. ${ }^{13}$ Policy-making under a 'procedural' view of democracy is 'determined either directly by the vote of the electorate or indirectly by officials freely elected at reasonably frequent intervals and by a process in which each voter who chooses to vote counts equally'. ${ }^{14}$ From that perspective, inter-party contestability may or may not emerge from an open structure of political participation whereas a notable degree of political contestability can be manifested through intra-party structures of competition and in non-partisan forms of political mobilization. In other words, it can be argued that inter-party contestation is not a constitutive element of democracy but simply a possible derivative from an open structure of participation.

From a procedural view of democracy, robust classification of regimes along the lines of democracy and authoritarianism rests upon the criterion according to which "process qualifies outcome' and not the other way around. ${ }^{15}$ In other words, the conceptual boundaries of 
authoritarianism must be drawn by assessing the nature of the process (or processes) that brings about a given political outcome. This distinction sets up a clear process for regime classification: to assess the democratic credentials of a dominant party system, it is necessary to identify a) which instruments and strategies limit inter-party contestability and b) pass a judgment whether they are compatible with basic standards of democratic process. If these instruments are found to contravene basic properties of democracy, the dominant party system can be classified as authoritarian. This is a fine distinction given the intricate conceptual and causal links between process and outcome but it is clear enough to guide this task: understandably, not any practice by which the incumbent government manages to limit its exposure to contestation amounts to an authoritarian restriction that would consequently qualify the regime as authoritarian, and dominant parties gain or lose democratic credentials along the democracy-authoritarianism continuum depending on the severity of the typical authoritarian restrictions they use. At first glance, a dominant party system cannot be classified as authoritarian as long as the electoral process is kept open to all citizens and their political organizations, and insofar as there is no serious and systematic application of fraud, intimidation or violence to force changes in the citizens' political behaviour against their free will. In that case, low degrees of inter-party contestability observed in a dominant party system can be interpreted as the genuine expression of electoral choice. Political competition takes place principally within the dominant party's internal structure and through other non-partisan forms of political organization. One may go as far as to suggest that political demands, expectations and grievances in those dominant party settings are adequately represented and advocated in central politics through the ranks of a single dominant party. On the contrary, dominant party systems are authoritarian when dominant parties are found to make use of extrademocratic means posing systematic limitations to the structure of political participation. ${ }^{16}$ 
Consequently, the classification of dominant party systems is problematic when they are found to employ a wider menu of manipulation to skew open multiparty elections in favour of the ruling party. ${ }^{17}$ This menu may primarily include the application of softer forms of electoral manipulation such as a range of distributive politics including clientelism and pork-barrel politics next to typical authoritarian controls that consist of the application of violence, intimidation, electoral fraud and systematic exclusions from political participation through reserved seats and biased electoral rules, and restrictions to voter and party registration, the freedom of the press and free campaigning. In actual empirical settings, clientelism has been contained in greater and more complex political structures with a varied 'continuum of repressive and participatory variations.' ${ }^{18}$ Clientelism has been recorded as a key strategy for dominant parties in numerous empirical setting: Japan, Mexico, Israel, Italy, Malaysia, Taiwan, Russia and other Former Soviet Republics, to name a few notable cases. ${ }^{19}$ In many cases, clientelist relations were often found to be 'reinforced' by the threat of direct forms of coercion. ${ }^{20}$

Nevertheless, it may be found that in many empirical settings the use of typical authoritarian controls has been patchy, sporadic or mostly responsive to crisis events or, in any case, not regular enough to sustain the dominant party in power, had it not been for a sufficient degree of actual popular support manifested in elections. The dominant party may impose authoritarian restrictions but these are unsystematic, and the party - unlike typical authoritarian regimes - is still dependent on popular support. ${ }^{21}$ The party is then heavily reliant on softer manipulative practices. Clientelism becomes a key, if not the primary, strategy by which the party could increase its popularity and fend off contestation by the opposition. ${ }^{22}$ Classification of highly clientelist dominant party systems is more problematic in those cases since the infrastructure for political repression is insufficient to secure incumbency in the event of falling popularity due to a relatively open electoral process. In that case the classification of the dominant party system 
largely depends on assessing the democratic credentials of clientelism, which is, nonetheless, observed in modern democracies too.

The critical question is how to gauge the regime's degree of authoritarianism. The crucial variable here is the extensive practice of clientelism defined by 'particularistic and contingencybased exchanges', creating vast relationships of 'contingency, hierarchy, and iteration.' ${ }^{23}$ If assessment is restricted to the range and severity of coercion and direct controls on political participation and expression, we may then place outside the sphere of authoritarianism those dominant party system that have not systematically used outright and direct restrictions to civil rights to a degree that blocks political participation but they have made extensive and systematic use of clientelism. However, we need a normative evaluation of clientelism given its distorting effect on political behaviour. To a large extent, this is where the conceptual ambiguity surrounding the regime status of dominant party systems lies: this is an empirical setting of limited inter-party contestability in a relatively open participation structure, there is extensive use of clientelism and at times a recorded scale of typical authoritarian controls that is, however, too erratic or unsystematic to account (exclusively or primarily) for the longevity of the incumbent's power monopoly. These empirical settings are understandably the greyest area in regime classification. The article suggests that regime classification should a) evaluate the contribution of soft manipulative practices such as clientelism to one-party dominance together with measuring the relative severity of typical authoritarian practices, and b) assess the democratic credentials of these practices as they have been applied in a particular socioeconomic and institutional context.

Given this recommended research direction, the purpose of the article is to clarify the conditions under which clientelism becomes an essentially authoritarian practice, and dominant party systems heavily reliant on that practice can be classified as authoritarian in accordance with 
the robust criterion that 'process qualifies outcome'. In the article's view, this criterion does not exclude prima facie the extension of the notion of authoritarian controls beyond the typical list to include non-violent manipulative tactics such as clientelism; yet, any conceptual extension has to be justified against a clear-cut definition of what an authoritarian practice is.

This task is highly problematic given the nature of clientelism as a 'contextually embedded phenomenon' that extends across a variety of regimes and may, or may not, overlap with democracy depending on the levels of competition and participation in the political system. ${ }^{24}$ First, the socioeconomic and political context in which clientelism unfolds may significantly shape its effect on citizens' behaviour. Second, ambiguity exists due to the various manifestations of clientelism as a political phenomenon that range from a form of particularistic politics in tune with the competitive nature of democratic process to a practice seriously distorting the terms of political competition to the extent that overall political behaviour could deviate substantially 'from that prescribed by (or expected from) the formal rules', ${ }^{25}$ at times helping the government party shield a power monopoly. When a dominant party system emerges out of this context, its position along the lines of democracy and authoritarianism largely depends on whether the terms under which clientelism takes place contravene basic democratic standards. Third, assessing the democratic credentials of various forms and types of clientelism may also stumble upon the persisting controversy over the very notion of democracy stemming from the presence of a thin and a thick definition. We are still in search of a clear line beyond which the practice of clientelism can be regarded as infringing basic elements of the democratic process. So far, prevailing current accounts of clientelism presented in more detail in the next section hold the view that clientelism is compatible with democratic process; actually a by-product of the highly antagonistic terms of political competition. Alternative arguments tend to emphasize clientelism as an abuse of state power which, when applied on a large scale, could limit political competition, but these arguments 
sketch out a rather controversial notion of 'authoritarian clientelism' based on Dahl's notion of inclusive hegemony and resort to his axiomatic position according to which limited inter-party contestability is a feature of a non-democracy.

These conceptual challenges require two interrelated theoretical undertakings: First, when seeking a standard for evaluating the democratic credentials of clientelism, we must give full credit to Dahl's definition of democracy and place it in the context of his broader work as a statement on democratic process too and not solely a typology based on regime characteristics. Important points of interface between contestability and procedural definitions regarding the basic requirements of democratic process are the capacity of citizens to contest political decisions and outcomes, and their freedom to determine their preferred course of political behaviour. Second, we must develop a convincing argument that clientelism or a particular type of clientelism contradicts these basic requirements. For that purpose, the prevalent current take on clientelism helps us keep a healthy distance from idealist projections of how citizenship and participation should be preferably

exercised. ${ }^{26}$ Instead, to consider clientelism as a practice whose extensive and systematic application renders a regime authoritarian we need an argument indicating that clientelism, or a type of clientelism, works in ways similar to typical authoritarian controls in restricting political participation and the contestability of political outcomes by the affected parties. Finally, this task must pay attention to the socioeconomic and political context in which clientelism is applied.

\section{Is clientelism compatible with democracy?}

The prevalent view in the literature sees clientelism as a common political pathology of modern and it stands quite far from declaring the practice as ipso facto authoritarian. ${ }^{27}$ Clientelist relationships are one of the many forms in which diverse social interests are represented and 
promoted, serving as a practical (although for some undesirable) solution to the problem of democratic representation. ${ }^{28}$ Clientelism emerges from two interrelated political processes: competition for office and competition for access to resources distributed by political power. On a micro-level, clientelist exchange involves an essentially consensual agreement for an exchange of benefits between the patron, a person of higher socioeconomic status, and the client, a person of lower status. ${ }^{29}$ As Stokes put it succinctly, 'the criterion of distribution that the patron uses is simply: did you (will you) support me? ${ }^{30}$ Although this form of exchange clearly departs from the ideal-types of 'principal-agent' and 'trustor-trustee' relationships in political representation, it is still compatible with the pragmatic terms under which democratic politics take place. Consequently, highly clientelistic dominant party systems can be considered as democratic regimes insofar as they offer voters and political actors an open structure for political participation. A line of reasoning can be derived that could go as follows: a) clientelism is one of the main tools employed by dominant parties to limit inter-party contestability, b) clientelism is a practice compatible with a democratic political system, and, consequently, c) a highly clientelistic dominant party system must be classified either as a democracy or a flawed democracy if the dominant party makes limited use of authoritarian controls but not to a degree sufficient to determine the electoral outcome, let alone shut down completely the formal structure of participation.

Nevertheless, the question of compatibility between clientelism and democracy is complicated by the effect widespread one-party clientelism could have on inter-party competition. Focusing on the distorting effect of government resources and non-violent manipulative uses of state power on competition, Greene, Levitsky and Way provide arguments why the extensive application of clientelism can be placed among the practices that render a dominant party system authoritarian. ${ }^{31}$ Greene uses Przeworksi's idea of 'meaningful elections' to draw a distinction 
between competitive authoritarian parties and predominant parties that emerge in conditions of 'more regular democratic turnover'. ${ }^{32} \mathrm{He}$ broadens the list of practices that make an election not 'meaningful' by including subtle manipulative tactics other than coercion which, nonetheless, significantly raise the organizational costs for the opposition to become an effective political contestant. ${ }^{33}$ Clientelism is one of the key practices affecting the participation decisions of social actors by changing the pay-offs they derive from alternative choices of political participation. As a result, extensive application of clientelism by the dominant party makes it more difficult for the opposition to recruit supporters and activists by raising its organizational costs to such an extent that competition with the incumbent is no longer meaningful. This gives the dominant party a degree of influence unmatched by any alternative political organization. Dominant party systems of that type bear a resemblance to Diamond's electoral hegemonies in the sense that the victory of the opposition party becomes an improbable event requiring a level of 'opposition mobilization, unity, skill, and heroism far beyond what would normally be required for victory in a democracy'.34

In a similar vein, the extensive practice of clientelism can be placed along other formal or informal restrictions to the opposition's access to resources, media, and the law. Their combined application in a given political arena could lead to the emergence of a 'competitive authoritarian' regime according to Levitsky and Way. ${ }^{35}$ More broadly, the politicization of state power and state bureaucracies skews the political playing field in favour of the incumbent. While this phenomenon is observed in democracies too, it is the scale of this abuse that substantiates the claim that oneparty dominance associated with these softer tactics of political manipulation is essentially authoritarian. Like Robert Dahl, Levitsky and Way elevate the notion of a 'reasonably level playing field' into a constitutive part of the definition of democracy. Yet the co-authors go one step further and place emphasis on the process by which this outcome is achieved. By asserting 
that a large scale of electoral manipulation via state power is unacceptable in a democracy, Levitsky and Way's solution to the conceptualization problem associates the political outcome (in essence, Dahl's limited contestability) with the systematic bias in favour of the incumbent that is produced by the use of state resources. Outcome is thereby linked to process. Even lawful exercises of state power can give the incumbent a source of advantage in electoral mobilization which instils unfairness in the terms of political competition.

The thin definition of democracy inspired by Dahl's polyarchy could now serve as a yardstick to assess not directly the nature of the dominant party system as an institutional outcome but, instead, the democratic credentials of clientelism as a process leading to that outcome. Clientelism is affecting the level and the quality of political participation. ${ }^{36}$ It could be argued that clientelism when reducing political contestability essentially becomes an authoritarian tool. The problem with this line of argument, however, lies in the fact that, when it comes to the application of soft manipulative practices, the conceptual boundaries between authoritarianism and democracy remain unspecified. A large scale of clientelism applied by political patrons to manipulate voting choices and political behaviour is observed in both authoritarian regimes and highly competitive political systems commonly regarded as democracies. A highly clientelistic competitive party system still exhibits distortions similar to those observed in a dominant party system, this time involving two or more clientelist parties that come to share a dominant position thanks to the advantages in political mobilization they derive through patronage. The scale of clientelism practised in many contemporary democratic systems secures both incumbents and all other parties that engage in clientelism strong electoral advantages versus outsiders. ${ }^{37}$ The playing field is again heavily skewed but this advantage is now shared by the clientelist political forces. Non-clientelist parties, on the other side, for instance minor parties, new entries and individual candidates that cannot engage in the supply of clientelism, face high informal barriers to entry. This creates a clear 
deficiency in the structure of representation, as substantive opportunities for multi-party contestability stemming from ideological and political differences, long-standing social cleavages and other emerging policy divisions are missed.

A possible response to this objection would point to the fact that, while the terms of political competition have been skewed in favour of the clientelist parties, many of today's highly clientelistic political systems have retained a degree of political competitiveness thanks to the existence of more than one clientelist parties. Thanks to the multi-party setting of political competition associated with decentralized distribution of clientelist supply there are competing and relatively autonomous political forces, and meaningful competition has survived. These highly clientelistic systems pass both Levitsky's and Way's criterion of what constitutes a fair level playing field and Greene's requirement for meaningful elections.. However, here is where the caveat to Greene's and Levitsky and Way's arguments returns. By focusing on the aggregate effect of clientelism on inter-party contestability this position resorts to the axiomatic position that the desired outcome (inter-party contestability) determines the type of regime, and only comes to delegitimize the regime when clientelism is found to reduce the degree of political competitiveness in favour of a single party.

We may be now close to understanding what is wrong with clientelism when applied on a large scale but we have not yet come up with a convincing argument why and when clientelism runs counter to core properties of democratic process, which must be the benchmark against which the democratic credentials of a regime must be assessed. The line may be narrowly defined by a rather uncontroversial interpretation of authoritarianism as the coerced imposition of political outcomes on citizens through violence and other outright restrictions and exclusions from participation. Alternatively, it can espouse Dahl's deontological view of inter-party contestability, 
this time as a criterion for assessing the legitimacy of the political means and tactics employed by the incumbent to limit its exposure to political competition - not as a benchmark to assess the regime output itself. From that perspective, Dahl's' notion of contestability can be read as a strong statement on the importance of associational activity in preventing one-group domination through mutual 'détente' among various social and political groups. ${ }^{38}$ What safeguards democracy is a delicate balance of power in which no group has enough resources to impose outcomes on all others. This system of mutual controls is secured when the cost of domination by one group is raised by the associational activity of others. ${ }^{39}$ In brief, Dahl's thesis on democracy adds to the notion of democratic process the requirement of 'guaranteed freedoms of association and expression'. ${ }^{40}$

This interpretation enables a synthesis between a thin, procedural definition of democracy and Dahl's more substantive thesis on contestability, this time with reference to the assessment of the processes, 'the methods', by which a political group keeps itself in power. The synthesis adopts a view of democratic process as an open competitive process in which citizens with equal rights and associational autonomy could contest political outcomes and decisions that affect their own circumstances and freely develop political activities to promote their interests and claims. This view understands democratic politics as competition for access to state power and acknowledges that state power can be the object of trade between politicians and citizens with their organizations through clientelism, a practice widespread in a large number of modern political systems. An authoritarian method is distinguished from a democratically compatible practice in the way it restricts citizens' capacity to contest the exercise of political power on them. The classification criterion shifts away from inter-party contestability as a regime trait and focuses on processes that bring about involuntary changes in citizen's behaviour under certain conditions. 
In that regard, a type of clientelism is authoritarian when it seriously damages citizens' capacity to contest political outcomes that affect them and forces changes in their political behaviour against their will. This type seems to be standing far away from the view of clientelism as a perverse yet legitimate form of voluntary exchange engaging free citizens, 'the clients', which is, however, compatible with democracy's pluralistic politics. If the nature of clientelism is to be assessed on account of its impact on citizens' capacities and freedoms, the task requires examining the multiple ways in which clientelism intersects the notion of democratic process defined as an open structure for citizens to participate, express their views and develop political activity. This evaluation calls for a broader observation of the multiple socioeconomic settings in which clients are situated, as well as of the implications regarding the contestability of clientelism beyond the dyadic relationship between patron and client. The second task requires assessing the full impact of clientelism on the availability and quality of substantive opportunities for citizens to contest political decisions that affect them.

\section{Clientelism as an illegitimate form of particularistic politics}

At first glance, clientelism appears to be a form of particularistic politics in tune with the clients' capacity for political participation and associational autonomy. Prospective clients and politicians enter an agreement by which they seek to maximize their utility, the latter achieving immediate and tangible returns possibly more significant than outcomes expected through other forms of political activity at collective level. Although the effect of clientelism on the quality of the political process could be viewed with a high degree of skepticism as an obstacle to the development of horizontal civil society organizations, ${ }^{41}$ a great loss to the processes of collective deliberation, mandate-making, and retrospective evaluations of governments, ${ }^{42}$ a restriction to the general benefits a society can gain from political representation, ${ }^{43}$ a corruption of the ideal relationship 
between citizens and politicians, ${ }^{44}$ and a hindrance to the attainment of broader political agendas, ${ }^{45}$ clientelism conforms to a realistic view of democratic process. Citizens are not required to articulate claims that appeal to broader categories of interest, ${ }^{46}$ and they can legitimately channel their political activity to promote special interests even to the detriment of others. Political power involves selection among conflicting demands articulated by self-interested actors. Democratic process bestows citizens with some bargaining resources to influence selection processes. Civil rights and liberties allow citizens to complain, protest, organize collective action to influence political decisions and openly dispute political outcomes. Their political activities aim at shifting the distribution of politically-allocated resources in their favour.

Clientelism becomes a realistic way for political and social actors to settle the allocation and distribution of goods and services. From a perspective stripped of idealistic views of democracy, it stems from the nature of politics as primarily particularistic by the very processes it unleashes. Clientelist exchange may demand their resignation from other forms of associational activities in return, but such resignation is voluntary. Just as government policies may be motivated by partisan gain rather than a genuine interest in general welfare, voters are free to use their rights for whatever payoff they think it is in their interest, even for the purpose of a cynical exchange of votes driven by humble motives in search of individualistic gains. ${ }^{47}$ In other words, citizens' autonomy extends to the freedom of clients to make effective use of their formal political rights as resources to bargain for politically distributed goods and services. This pragmatic approach of democracy indicates the gap that separates 'what is theoretically desirable and what is practically possible' ${ }^{48}$ To expect universalism in politics is unrealistic, unattainable and possibly not desirable. ${ }^{49}$ From that perspective, we may consider clientelist exchange as corrupt practices, but this does not provide a convincing conceptual basis upon which to support the incompatibility thesis. The opposite view stressing the corrosive effects of clientelism on citizenship is a 
normative statement that inevitably reflects subjective and often controversial standards of how citizenship should be exercised. ${ }^{50}$

Nevertheless, the prevalent take on clientelism can be criticized for overlooking a crucial aspect of the phenomenon: the contestability of the negative externalities of clientelist exchanges by third parties affected by discrimination and favouritism. If the essence of democratic process is to offer citizens substantive opportunities for contesting political decisions, formal channels should be available for the settlement of competing claims and grievances by those disaffected by particularistic allocations. The democratic process is not expected to eliminate negative externalities emerging from selection via the political process and cannot prevent any perceived misallocations and injustices of political particularism. Yet 'going public' may mitigate the problem of the negative effects from political decisions and may increase the possibility that political selection will not systematically exclude a set of preferences and interests. Advocates of democratic process may hold the optimistic expectation that, in responding to competing demands that are articulated through formally open processes of debate and deliberation, the government will tend to deliver public policies that approximate prevalent perceptions of 'common interest'. Others may simply expect that an openly debated selection process tends to put in place some societal checks on the discretion enjoyed by government power. From that perspective, a selection process in the allocation of goods and services by political power is democratically legitimate insofar as it is performed through the formal channels that allow political representation and advocacy exactly because this allows citizens disaffected by particularistic allocations to contest decisions and outcomes in a relatively open and transparent way. Again, associational autonomy and the capacity to contest political outcomes including particularistic allocations distinguish legitimate from illegitimate forms of particularistic politics. 
If particularistic politics conform to basic properties of the democratic process, insofar as there are substantive opportunities enabling all citizens to check the selection process and challenge in public debate particularistic allocations that have a negative impact on them, porkbarrel politics defined as the selective allocation by politicians of a public resource to a given constituency or group in anticipation of public support may well conform to this standard. The requirement of publicity and exposure to debate is likely to be met by virtue of the open, formalistic and often legislative process by which these allocations are typically agreed upon and the size of the allocations involved. While pork-barrel politics - like clientelism - is a form of favouritism deliberately employed as a political mobilization strategy, ${ }^{51}$ as long as the scale and process of pork-barrel politics make these allocations visible and thus exposed to public debate, the practice meets the above-mentioned standard of democratic process despite the negative costs a pork-barrel allocation may produce on general welfare. The same criterion would assess the contestability of negative externalities emerging from clientelist exchange: are there any substantive opportunities available to citizens to detect, expose and challenge the negative impact they experience from clientelist allocations?

The targeted and often individualistic nature of clientelist favours tends to differ from other forms of redistributive politics in terms of visibility and the degree of public interest each specific case is likely to raise. First, while the practice of clientelism is an 'open secret' - at times creating strong reputations for patrons that attract new clients and preserve old ones, clientelist agreements are typically reached 'behind closed doors', meaning that other actors with a direct interest at stake cannot easily identify and bring the issue to open debate, particularly at the time when negotiations take place between the patron and the client. Clientelist exchanges are deliberately designed to avoid transparency and bypass public scrutiny so that other affected parties are deprived of the opportunity to be aware of them prior to the agreement or challenge 
them through formal institutional channels afterwards. Second, even when a given clientelist agreement becomes visible, the granting of selective benefits may directly affect a few isolated actors. Inevitably, the capacity of third parties to contest these allocations largely relies on the availability of advocacy by existing political organizations, most often the parties and politicians of the opposition. These political agents would most probably decide to engage resources to track a specific case when it is likely to elicit a substantive degree of public interest. Importantly enough, public interest in a specific case of favouritism depends on the magnitude of the clientelist favour and the number of the people affected by it. It is thus quite likely that political opponents may decide not to devote scarce political resources to track and challenge specific cases of discrimination and favouritism and, instead, limit themselves to generic criticism of the prevalence of clientelism as a political phenomenon. Visibility and contestability of specific clientelist allocations may be further reduced under the circumstances of a dominant party system where political resources in the hands of minor political parties are in shorter supply. Eventually, specific cases of favouritism, each affecting a limited number of social actors, will generally go uncontested. On the contrary, both the opacity of individual clientelist transactions and the prevalence of clientelism as a general phenomenon could further reduce the contestability of its clientelist allocations by strengthening the party's mobilization power on the political actors who could have tracked these cases.

\section{Clientelism as authoritarian control of political behaviour}

The second task is to explore the conditions under which clientelism could be equated with typical authoritarian controls in the way it restricts the freedom of citizens to make effective use of their formal political rights, forcing citizens to adjust their political behaviour against their will by threatening harm. Clientelism, or at least a particular form of clientelism, infringes democratic 
process if it is found to work in that way. The line separating authoritarian and non-authoritarian ways to manipulate behaviour is defined here by the distinction between coerced versus voluntary behavioural change.

At first glance, clientelism seems to differ considerably from the way typical authoritarian practices force changes in political behaviour. State power is employed in both cases, but the exercise of physical violence and intimidation, by threatening personal freedom, physical integrity and possibly life, deprives individuals of the basic freedom to choose a preferred course of action. Clientelist incentives and disincentives do not entail the obvious restrictions that coercion places on choice which force adaptations in behaviour against one's will. Quite the opposite, clientelist incentives trigger voluntary adaptive responses by self-interested actors. The relationship between patrons and clients seems to reflect a consensual agreement by which they both anticipate significant gains. One may go as far as to suggest that the availability of clientelism in a democracy broadens the citizens' options in their attempt to gain access to resources by adding a new range of returns to the value of their vote and political activity. Even though clientelist exchange is a highly hierarchical relationship by which clients enter a sphere of authority, insofar as clientelist incentives do not force citizens to change unwillingly their behaviour, and prospective clients have the freedom to accept or deny the rewards offered, clientelism manipulates behaviour in a non-coercive way and the impact of clientelism on political behaviour cannot be equated with typical authoritarian controls over political behaviour.

This notion of clientelism as a voluntary transaction may be challenged by those pointing to the involvement of state power- by its very nature authoritative and coercive - in clientelist exchange. The power asymmetry in clientelist exchange is further sharpened by the imbalance between demand and supply - on the one side myriads of prospective clients aspiring to enter into 
a clientelist exchange and, on the other, the much smaller number of patrons with the political power to meet these demands. Competition on the demand side means that only a small number of powerful clients will be able to negotiate the terms of the agreement. This disparity exacerbates the gap in bargaining power between patrons and clients, allowing the patrons to raise the 'price' charged, i.e. the reciprocation required in return of the granted favour, and undermining accountability from their part. ${ }^{52}$ Clientelist exchange under power asymmetry resembles the type of contract in which one party leaves no choice to the consumer other than 'take it or leave it'. A first response to this objection, however, could point out that asymmetrical power relations exist in all forms of particularistic politics. Just as any political relationship, clientelism involves asymmetrical power in the process of selection and exclusion for the distribution of resources, ${ }^{53}$ and this asymmetry alone cannot equate clientelism with typical authoritarian practices that directly restrict citizen's autonomy and associational capacity. Yet, as the degree of asymmetrical power varies, we may again ask the question whether asymmetrical power relations under clientelism may go as far as to create a structure of political dominance and citizens' subordination.

This question emerges when the negative side of clientelism comes under scrutiny; when citizens who do not fulfil their duties and commitments as clients face discrimination in the allocation of goods and services provided by means of patronage supply. ${ }^{54}$ The efficacy of a clientelist strategy in demanding behavioural changes is associated not simply with the capacity of patrons to reward clients but also with their capacity to punish dissenters and defectors by exclusion, discrimination and material retaliation. Retaliatory measures may include, for instance, dismissals, unfavourable job placements, refusal to grant a license, serious delay in the delivery of government services, refusal to provide credit from state-controlled banks, discriminatory tax controls etc. Equally punishing can be the exclusion from a wide array of discretionary favours 
that are only available to co-opted social and economic actors. In both cases, exclusion and discrimination are sanctions imposed by patrons to punish political defiance, defection or mere political apathy as behavioural choices. These clientelist disincentives oblige actors embedded in a clientelist political context to make a risk assessment whose parameters vary on the basis of one's socioeconomic position and degree of risk aversion, and shall involve:

- Assessing the severity of the cost one may suffer, given one's social and economic status (impact assessment)

- Evaluating the probability that a particular course of behaviour bring about a penalty. Risk assessment will look at the rate of occurrence of penalties attached to the behaviour under consideration, which is traced in the frequency of relevant incidents by the government acts (signaling probability).

- Evaluating the possibility of mitigation or compensation by looking at whether there are opportunities for exit to spheres of private economic activity relatively autonomous from clientelist practices.

A substantially large number of reported or rumoured cases of economic retaliation indicate high probability that the same sanction will be imposed on anyone who considers following a similar path of behaviour in the future. The severity of punishments serves as a warning signal to prospective and existing clients about the high cost of dissent or defection. The effectiveness of the sanction is strengthened when there are limited opportunities to avoid or offset the losses from the sanction imposed. This depends on the opportunities available to economic and social actors to develop activity in spheres that remain relatively autonomous from clientelist incentives. This is also contingent on the availability of other antagonistic networks for clientelist exchange that could offer dissenting citizens protection, patronage and compensation for current losses and 
sanctions. The larger the range of activities subject to clientelist incentives and disincentives, and the more limited the presence of clientelist networks, the lower the chances one has to avoid the range of clientelist disincentives imposed by the incumbent.

Ultimately, the scope for exit from clientelist disincentives imposed by the incumbent defines one's degree of freedom to choose freely a desired path of political behaviour. When exclusion and discrimination cannot be avoided, the cost may be high enough to force individuals to alter their political conduct to avoid imminent sanction. The opportunity cost of the sanctioned course of behaviour is raised to levels comparable to the costs imposed on dissenting political behaviour by means of coercion in authoritarian regimes. When clientelist discrimination and exclusion reach a degree and intensity that essentially deprives individuals of free choice, clientelism works in similar ways as coercive power and ceases to be compatible with democratic process. This is authoritarian clientelism that punishes 'voice' by depriving exit, ${ }^{55}$ triggering involuntary adjustments in one's political behaviour.

Conditions of limited exit from clientelist sanctions are observable in party systems that exhibit two structural characteristics: a) the dominant party has a monopoly or near monopoly over the supply of clientelism and there are no sizeable antagonistic clientelist networks to compensate citizens for current losses and sanctions, and b) the economy is 'highly politisized' in the sense that a significantly large share of resources is being administered and accessed via clientelist exchange and there is no substantial room for citizens to develop social and economic activities outside the reach of clientelist incentives. In that context, there are blockages to 'exit' and material punishments sanctioning 'voice', from which individuals cannot opt out without suffering serious and inescapable damage to their welfare. The extensive application of clientelism in a dominant party system with a highly politicized economy becomes essentially coercive, a direct restriction to 
political freedom in a way similar than coercion. The aggregate pattern of behaviour adaptive to clientelist incentives under these conditions can be seen as the result of forced integration into a structure of subordination, and classifies the dominant party system as authoritarian.

\section{Conclusion}

When sorting out the position of highly clientelistic dominant party systems that retain a relatively open structure of participation along the lines of democracy and authoritarianism, classification largely relies on assessing the nature of clientelism under practice. This task awaits a fuller analysis of clientelism as a subset of particularistic politics that would explore which manifestations of this practice are not compatible with basic elements of democratic process. It is also complicated by seemingly distinct approaches derived from a thin and a thick definition of democracy that give a different verdict on the effect of clientelism on inter-party contestability.

The article has proposed a synthesis toward a notion of democratic process that incorporates contestability into the standard by which to assess clientelism. Democratic process is defined here primarily as the availability to citizens of real and substantive opportunities to periodically exercise control over political elites as well as the autonomy and capacity to contest political decisions that affect them. The task shifts away from measuring the impact of clientelism on inter-party contestability - which may be affected by manipulative practices compatible with democracy - to assess its impact on citizen's capacity and autonomy in the socioeconomic and political context in which citizens are situated. 
The article first assesses the nature of clientelism against the basic democratic requirement that political decisions involving allocation and selection should be exposed to open debate and deliberation. Although clientelist exchange results from agreement between the patron and the client, the negative externalities it generates must be contestable by the disaffected third parties. The article indicates the conditions under which clientelism prevents third parties from challenging discrimination and favouritism and, therefore, becomes an illegitimate form of particularistic politics. The degree to which this deficiency is serious enough to compare with typical authoritarian controls depends on the range of the resources available for contestation, which are again highly contingent on the scale of clientelism under practice and the availability of political resources. These resources are particularly scarce under the circumstances of a dominant party system.

The second argument focuses on the opportunity cost for the citizens to follow their preferred course of political behaviour in defiance of clientelist incentives and disincentives. Clientelism is essentially authoritarian when it is found to affect citizens' behavioural choices in similar ways to typical coercion. This happens when the opportunity cost is raised to a degree that prospective clients have no real choice to accept or deny the rewards offered and are essentially deprived of the freedom to opt out of clientelist exchange and avoid informal sanctions. This can be observed in the way exclusion and material retaliation under a dominant party system could force involuntary changes in political behaviour in the context of a highly politicized economy, as social actors lack exit to spheres of economic activity relatively protected from government discrimination.

\section{Notes}


1 Bogaards 'Counting Parties' and Bogaards and Boucek Dominant Political Parties, opting for the democracy/non-democracy dichotomy adopted by Huntington, The Third Wave, 11.

2 C.f. Linz and Stepan, Problems of Democratic Transition and Consolidation; Eke and Kuzio, 'Sultanism in Eastern Europe'; Colton and McFaul, Popular Choice and Managed Democracy; Gill, Democracy and Post-Communism; Croissant, 'From Transition to Defective Democracy'; Merkel, 'Embedded and Defective Democracies'; Schedler 'The Menu of Manipulation'; Wegren and Konitzer, 'Federalism and Political Recentralization'.

3 Diamond, 'Elections without Democracy'.

$4 \quad$ Schedler 'The Menu of Manipulation'.

5 Levitsky and Way, Competitive Authoritarianism; and Linz and Stepan, Problems of Democratic Transition and Consolidation.

6 Diamond, 'Elections without Democracy', 24.

7 Pempel, 'Introduction'; Ware, Political Parties and Party Systems, 159 and 165; Giliomee and Simkins, The Awkward Embrace.

8 Sartori, Parties and Party Systems, 194, referring to Mexico's Institutional Revolutionary Party (PRI).

9 Storm, 'An Elemental Definition of Democracy', 217.

10 Dahl, Polyarchy: Participation and Opposition, 1-9.

11 Dahl, Polyarchy: Participation and Opposition, 8, 34.

12 As argued by Giliomee and Simkins, The Awkward Embrace.

13 Schumpeter, Capitalism Socialism and Democracy, 269.

14 Pennock, Democratic Political Theory, 9; Authors who also adopt a procedural definition of democracy include Lipset, Political Man,45; Sartori, Democratic Theory, 126; and Popper, $T$ he Open Society and Its Enemies, 132. 
15 Bogaards, 'Counting Parties and Identifying Dominant Party Systems in Africa', 178.

16 Bogaards, 'Counting Parties and Identifying Dominant Party Systems in Africa', 178.

17 Schedler, 'The Menu of Manipulation', 3; c.f. Levitsky and Way Competitive Authoritarianism.

18 Hilgers, Clientelism and Conceptual Stretching, 568.

19 In Japan, Scheiner, Democracy without Competition, Israel, 'Introduction', 21; Mexico, Fox, The Politics of Food in Mexico; Greene, 'A Resource-theory of Single-Party Dominance'; Holzner, Poverty of Democracy; Magaloni Voting for Autocracy; Italy, Tarrow, Between Center and Periphery; Golden and Picci, 'Pork Barrel and Distributive Politics'; Malaysia, Giliomee and Simkins, The Awkward Embrace: xvi; and in the former Soviet republics and Eastern Europe, Evans and Whitefield, 'Identifying the Bases of Party Competition', 545-546; and Eke and Kuzio, 'Sultanism in Eastern Europe', among others. Fox, The Politics of Food in Mexico, 7.

21 As Pempel put it, 'a dominant party must gain at least an electoral plurality, which means dominance in socioeconomic mobilization', 'Introduction', 16.

22 See Fox, 'The Difficult Transition from Clientelism to Citizenship', 155; Scheiner,Democracy without Competition in Japan; Magaloni, Voting for Autocracy, chapters 1 to 4; Greene, 'A Resource-theory of Single-Party Dominance'.

23 Hicken, 'Clientelism'.

24 See Hilgers 'Democratic Processes' 4; and 'Clientelism and Conceptual Stretching', 574.

25 Helmke and Levitsky, Informal Institutions and Democracy, 2. C.f. Roniger, 'The Comparative Study of Clientelism', on the divergence in views on the normative compatibility of clientelism with democracy seen through the lens of a Weberian ideal-type, 10. 
27 See Weingrod, 'Patrons, Patronage, and Political Parties'; Tarrow Between Center and Periphery; Clapham, Private Patronage and Public Power; Mavrogordatos, StillBorn Republic; Eisenstadt and Roniger, Patrons, Clients and Friends; Lyrintzis, 'Political Parties in Post-Junta Greece'; Roniger and Güneş-Ayata, Democracy, Clientelism and Civil Society; Gay, 'Rethinking Clientelism'; Kitschelt, 'Linkages between Citizens and Politicians'; Kristinsson, 'Clientelism in a Cold Climate'; Piattoni Clientelism, Interests, and Democratic Representation, Robinson \& Verdier 'The Political Economy of Clientelism'; Kitschelt and Wilkinson, 'Citizen-Politician Linkages'; Van de Walle, 'Meet the New Boss'; Holzer, Poverty of Democracy.

28 Piattoni, Clientelism, Interests, and Democratic Representation, 3; Holzner, Poverty of Democracy, 46. Shefner, 'What is Politics', 42. Günes-Ayata, Clientelism: Premodern, Modern, Postmodern, 22 and 26.

Landé, 'Introduction', xx; similar definitions by Scott, Comparative Political Corruption, 92; Lemarchand and Legg, 'Political Clientelism and Development', 150; and Kaufman, 'The Patron-Client Concept and Macro-Politics',285.

30 Stokes, 'Political Clientelism', 605.

31 Greene, 'A Resource-theory of Single-Party Dominance' and 'The Political Economy of Authoritarian Single-Party Dominance'; and Levitsky and Way, Competitive Authoritarianism.

32 Greene, 'The Political Economy of Authoritarian Single-Party Dominance', 810; and Przeworski, Alvarez, Cheibub and Limongi, Democracy and Development.

33 Greene, 'A Resource-theory of Single-Party Dominance', 156 and 158.

34 Diamond, 'Elections without Democracy', 24.

35 Levitsky and Way, Competitive Authoritarianism. 
36 Just as 'the formal institutional makeup' does, see Shefner, 'What is Politics', 42

37 See Clapham, Private Patronage and Public Power; Eisenstadt and Roniger, Patrons, Clients and Friends; Roniger and Günes-Ayata, Democracy, Clientelism and Civil Society; and Piattoni, Clientelism, Interests, and Democratic Representation.

Dahl, Dilemmas of Pluralist Democracy, 36, 43.

40 Fox, 'The Difficult Transition from Clientelism to Citizenship', 152.

41 See Scott, Comparative Political Corruption.

42 Stokes on vote-buying, 'Is Vote-Buying Undemocratic', 132.

43 Escobar, 'Clientelism and Citizenship'.

44 See Barnes and Sani, 'Mediterranean Political Culture and Italian Politics'; Zuckerman, 'Clientelist Politics in Italy', Shefner 'What is Politics For'; Volintiru, 'Clientelism and Democratic Accountability'.

45 See Littlewood, 'Patrons or Bigshot'; Schneider, Schneider and Hansen, 'Modernization and Development'.

46 C.f. Putnam, Making Democracy Work.

47 See Huntington, The Third Wave, 10.

48 Piattoni, Clientelism, Interests, and Democratic Representation, 18; c.f. Weingrod, 'Patrons, Patronage, and Political Parties'; Lemarchand and Legg, 'Political Clientelism and Development'; Gay, 'Rethinking Clientelism'; Blakeley, 'Building State and Civil Society', 79.

49 Piattoni, Clientelism, Interests, and Democratic Representation, 29.

50 For similar objections see Huntington, The Third Wave and Schumpeter, Capitalism Socialism and Democracy, chapters 20-22. 
51 See Forewaker and Landman, Citizenship Rights and Social Movements; and Ansolabehere and Snyder Party Control of Government.

52 See Lyne, 'The Voter's Dilemma and Democratic Accountability'.

53 C.f Günes-Ayata, Clientelism: Premodern, Modern, Postmodern, 24.

See Stokes 'Perverse Accountability' and Lyne, 'The Voter's Dilemma and Democratic Accountability'

55 Terms first articulated by Hirschman, Exit, Voice and Loyalty. 
References

Ansolabehere Stephen and James M. Snyder Jr. Party Control of Government and the Distribution of Party Expenditures, MIT Department of Economics Working Paper No.03-28, 2002.

Barnes Samuel H., and Giacomo Sani. 'Mediterranean Political Culture and Italian Politics: An Interpretation'. British Journal of Political Science 4, no. 3 (1974): 283-305.

Blakeley, Georgina. 'Clientelism in the Building of State and Civil Society in Spain'. In Clientelism, Interests and Democratic Representation: the European Experience in Historical and Comparative Perspective, edited by Simona Piattoni, 77-100, Cambridge: Cambridge University Press, 2001.

Bogaards, Maththijs, 'Counting Parties and Identifying Dominant Party Systems in Africa'. European Journal of Political Research, 43, no. 2 (2004): 173-197.

Bogaards, Maththijs, and Boucek Francoise. Dominant Political Parties and Democracy. London: Routledge, 2010.

Boucek, Françoise, 2012, Factional Politics: How Dominant Parties Implode or Stabilize. London: Palgrave Macmillan.

Clapham, Christopher. Private Patronage and Public Power: Political Clientelism in the Modern State. London: Frances Pinter, 1982. 
Colton Timothy J. and Michael McFaul. Popular Choice and Managed Democracy: The Russian Elections of 1999 and 2000. Washington DC: Brookings Institution Press, 2003.

Croissant, Aurel. 'From Transition to Defective Democracy: Mapping Asian Democratization'. Democratization 11 no. 5 (2004), 156-178.

Dahl, Robert. Polyarchy: Participation and Opposition, New Haven, CT: Yale University, 1971.

Dahl Robert, Dilemmas of Pluralist Democracy: Autonomy vs. Control, New Haven: Yale University Press, 1982.

Diamond, Larry. 'Elections without Democracy: Thinking About Hybrid Regimes'. Journal of Democracy, 13 no.2 (2002), 21-35.

Dixit, Avinash and John Londregan. 'The Determinants of Success of Special Interests in Redistributive Politics'. Journal of Politics 58, no.4 (1996), 1132-1155.

Eke, Steven M.; Taras Kuzio. 'Sultanism in Eastern Europe: The Socio-Political Roots of Authoritarian Populism in Belarus'. Europe-Asia Studies 52, no.3 (2000), 523-547.

Eisenstadt, Shmuel Noah and Luis Roniger. Patrons, Clients and Friends: Interpersonal Relations and the Structure of Trust in Society. Cambridge: Cambridge University Press, 1984.

Escobar, Cristina. 'Clientelism and Citizenship: The Limits of Democratic Reform in Sucre, Colombia'. Latin American Perspectives, 29, no.5 (2002), 20-47. 
Forewaker, Joe and Todd Landmann. Citizenship Rights and Social Movements: A Comparative and Statistical Analysis. Oxford: Oxford University Press, 1997.

Fox, Jonathan. The Politics of Food in Mexico: State Power and Social Mobilization. Ithaca: Cornell University Press, 1993.

Fox, Jonathan. The Difficult Transition from Clientelism to Citizenship: Lessons from Mexico. World Politics 46, no, 2 (1994), 151-184.

Gay, Robert. 'Rethinking Clientelism: Demands, Discourses and Practices in Contemporary Brazil'. European Review of Latin American and Caribbean Studies, 65 (1998), 7-24.

Giliomee, Hermann and Charles Simkins. The Awkward Embrace: One-Party Domination and Democracy. Sydney Australia: Harwood Academic Publishers, 1999.

Gill, Graeme. Democracy and Post-Communism. London: Routledge, 2001.

Golden, Miriam A. and Lucio Picci. 'Pork Barrel and Distributive Politics in Post-war Italy, 19531992'. American Journal of Political Science 52, no. 2 (2008), 268-289.

Greene, Kenneth, F. Why Dominant Parties Lose: Mexico's Democratization in Comparative Perspective, New York: Cambridge University Press. 2007.

Greene, Kenneth F. 'A Resource-theory of Single-Party Dominance: The PRI in Mexico'. In Dominant Political Parties and Democracy edited by Maththijs Bogaards, and Francoise Boucek,. 155-174. London: Routledge, 2010. 
Greene, Kenneth, F. 'The Political Economy of Authoritarian Single-Party Dominance'. Comparative Political Studies 43 no. 7 (2010), 807-834.

Güneş-Ayata, Ayşe. 'Clientelism: Premodern, Modern, Postmodern'. In Democracy Clientelism and Civil Society edited by Luis Roniger and Ayse Günes-Ayata, 19-28. Lynne Rienner Publishers, 1994.

Helmke Gretchen and Steven Levitsky. 'Introduction'. In Informal Institutions and Democracy, Lessons from Latin America edited by Gretchen Helmke and Steven Levitsky, 1-32. Baltimore: Johns Hopkins, 2006.

Hicken, Allen. 'Clientelism'. Annual Review of Political Science 14, no. 1 (2011), 289-310

Hilgers, Tina. 'Clientelism and Conceptual Stretching: Differentiating among Concepts and among Analytical Levels'. Theory and Society, 40, no. 5 (2011), 567-588.

Hilgers, Tina. 'Democratic Processes, Clientelistic Relationships, and the Materials Goods Problem'. In Clientelism in Everyday Latin American Politics edited by Tina Hilgers, 1-24. Basingstoke: Palgrave Mcmillan, 2012.

Hirschman, Albert O. Exit, Voice and Loyalty: Responses to Decline in Firms, Organizations and States. Cambridge Mass: Harvard University Press, 1970.

Holzner A. Claudio. Poverty of Democracy: The Institutional Roots of Political Participation in Mexico. Pittsburgh University Press, 2010. 
Huntington. Samuel P. The Third Wave: Democratization in the Late Twentieth Century. Norman: University of Oklahoma Press, 1991.

Kaufman, Robert. 'The Patron-Client Concept and Macro-Politics: Prospects and Problems'. Comparative Studies in Society and History 16, no. 3 (1974), 284-308.

Kitschelt, Herbert. 'Linkages between Citizens and Politicians in Democratic Polities'. Comparative Political Studies 33 no.6/7 (2000), 845-879.

Kitschelt, Herbert and Wilkinson, Steven I... 'Citizen-Politician Linkages'. In Patrons, Clients, and Policies: Patterns of Democratic Accountability and Political Competition edited by Herbert Kitschelt and Steven I. Wilkinson, 1-49. Cambridge: Cambridge University Press, 2007.

Kristinsson, Gunnar Helgi. 'Clientelism in a Cold Climate: the Case of Iceland'. In Clientelism, Interests, and Democratic Representation: the European Experience in Historical and Comparative Perspective edited by Simona Piattoni, 172-192. Cambridge: Cambridge University Press, 2001.

Korosteleva, Elena A. 'Is Belarus a Demagogical Democracy?'. Cambridge Review of International Affairs 16 no. 3 (2003), 525-533.

Landé, Carl, H. 'Introduction: The Dyadic Basis of Clientelism'. In Friends, Followers and Factions edited by Steffen W. Schmidt, James Scott, Carl Landé and Laura Guasti, xiii-xxxii. Berkeley: University of California Press, 1977. 
Lemarchand Rene and Keith Legg. 'Political Clientelism and Development: A Preliminary Analysis'. Comparative Politics 4 no. 2 (1972), 149-172.

Levitsky, Stephen and Lucan A. Way. Competitive Authoritarianism: Hybrid Regimes After the Cold War. Cambridge: Cambridge University Press, 2010.

Lindbeck, Assar, and Jorgen Weibull. 'Balanced-budget |Redistribution as the Outcome of Political Competition'. Public Choice 52 no. 3 (1987): 273-297.

Linz Juan and Alfred Stepan. Problems of Democratic Transition and Consolidation: Southern Europe, South America, and PostCommunist Europe. Baltimore, MD: Johns Hopkins University Press, 1996.

Lipset, Seymour Martin. Political Man: The Social Bases of Politics. London: Heinemann, 1960.

Littlewood, Paul. 'Patrons or Bigshots: Paternalism, Patronage and Clientelist Welfare in Southern Italy’. Sociologia Ruralis 21 no.1 (1981), 1-15.

Lyrintzis, Christos. 'Political Parties in Post-Junta Greece: A Case of “Bureaucratic Clientelism?'. West European Politics 7 no. 2 (1984), 99-118.

Magaloni, Beatriz. 2006. Voting for Autocracy: Hegemonic Party Survival and Its Demise in Mexico. New York: Cambridge University Press. 
Mainwaring, Scott. Rethinking Party Systems in the Third Wave of Democratization: The Case of Brazil. Stanford CA: Stanford University Press, 1999.

Mavrogordatos George Th.. StillBorn Republic: Social Coalitions and Party Strategies, 19221936. Berkeley: University of California Press, 1983.

Merkel, Wolfgang. 'Embedded and Defective Democracies'. Democratization 11 no.5 (2004), 3358.

Pempel, T. J. 'Introduction'. In Uncommon democracies: The One-Party Dominant Regimes edited by T. J. Pempel, 1-32. Ithaca: Cornell University Press, 1990.

Pennock, J. Roland. Democratic Political Theory. Princeton: Princeton University Press, 1979.

Piattoni, Simona, ed. Clientelism, Interests, and Democratic Representation: the European Experience in Historical and Comparative Perspective. Cambridge: Cambridge University Press, 2001.

Popper, Karl. The Open Society and Its Enemies: The Spell of Plato, London: Routledge, 2002.

Przeworski, Adam, Michael Alvarez, José Antonio Cheibub and Fernando Limongi. Democracy and Development: Political Institutions and Well-Being in the World, 1950-1990. Cambridge: Cambridge University Press, 2000. 
Putnam, Robert D. Making Democracy Work: Civic Traditions in Modern Italy. Princeton: Princeton University Press, 1993.

Robinson, James, A. and Thierry Verdier. 'The Political Economy of Clientelism'. CEPR Discussion Paper No. 3205, 2002.

Roniger, Luis. 'The Comparative Study of Clientelism and the Changing Nature of Civil Society in the Contemporary World'. In Democracy, Clientelism and Civil Society edited by Luis Roniger and Ayşe Güneş-Ayata, 1-18. Boulder: Lynne Rienner, 1994.

Sartori, Giovanni. Democratic Theory, New York. Washington, London: Praeger, 1967.

Sartori, Giovanni. Parties and Party Systems: A Framework for Analysis, Cambridge: Cambridge University Press, 2005 (1976).

Schedler, Andreas. 'The Menu of Manipulation'. Journal of Democracy 13 no.2 (2002), 36-50.

Scheiner, Ethan. 2005. Democracy without Competition in Japan: Opposition Failure in a OneParty Dominant State (New York: Cambridge University Press).

Schneider Peter, Jane Schneider and Edward Hansen. 'Modernization and Development: the Role of Regional Elites and Noncorporate Groups in the European Mediterranean'. Comparative Studies in Society and History 14 no. 3 (1972), 328-350. 
Schumpeter, Joseph Alois. Capitalism Socialism and Democracy. London: Routledge, 1976.

Scott, James. Comparative Political Corruption. Englewood Cliffs, NJ: Prentice Hall, 1972.

Shefner, Jon. 'What is Politics For? Inequality, Representation, and Needs Satisfaction under Clientelism and Democracy'. In Clientelism in Everyday Latin American Politics edited by Tina Hilgers, 41-59. Basingstoke: Palgrave Mcmillan, 2012.

Silverman, Sydel F. 'Exploitation in Rural Central Italy: Structure and Ideology in Stratification Study'. Comparative Studies in Society and History 12 no. 3 (1970), 327-339.

Stokes, Susan C. 'Perverse Accountability: A Formal Model of Machine Politics with Evidence from Argentina'. American Political Science Review 99, no. 3 (2005), 315-325.

Stokes, Susan C. 'Political Clientelism'. In The Oxford Handbook of Political Science edited by Charles Bois and Susan C. Stokes, 602-627. Oxford: Oxford University Press, 2007.

Storm, Lise. 'An Elemental Definition of Democracy and its Advantages for Comparing Political Regime Types'. Democratization 15 no. 2 (2008), 215-229.

Tarrow, Sidney. Between Center and Periphery: Grassroots Politicians in Italy and France. New Haven, CT: Yale University Press, 1977. 
Tarrow, Sidney, 1990, 'Maintaining Hegemony in Italy: “The Softer they Rise, the Slower they Fall"”, in T.J. Pempel (ed.) Uncommon Democracy: The One-Party Dominant Regimes, Ithaca: Cornell University Press, 306-332.

Van De Walle, Nicolas. 'Meet the New Boss, Same as the Old Boss? The Evolution of Political Clientelism in Africa'. In Patrons, Clients, and Policies: Patterns of Democratic Accountability and Political Competition edited by Herbert Kitschelt and Steven I. Wilkinson, 50-67. Cambridge: Cambridge University Press, 2007.

Volintiru, Clara. 'Clientelism and Democratic Accountability', PSA Graduate Network Conference, 2010.

Ware, Alan. Political Parties and Party Systems. Oxford: Oxford University Press, 1996.

Wegren Stephen and Andrew Konitzer. 'Federalism and Political Recentralization in the Russian Federation: United Russia as the Party of Power'. Publius 36 no. 4 (2006), 503-522.

Weingrod, Alex. 'Patrons, Patronage, and Political Parties'. Comparative Studies in Society and History 10 no. 4 (1968), 377-400.

Whitefield, Stephen and Geoffrey Evans, 1993, 'Identifying the Bases of Party Competition in Eastern Europe'. British Journal of Political Science, 23 no. 4 (1993), 521-548.

Zuckerman Alan S. 'Clientelist Politics in Italy'. In Patrons and Clients in Mediterranean Societies edited by Ernest Gellner and John Waterbury, 63-79. London: Duckworth, 1977. 